\title{
Results of Fetal Ultrasound Imaging and Doppler Ultrasound Study Depending on the Factors of Perinatal Risk in Preterm Birth
}

\author{
Agamurad A. Orazmuradov, $\mathrm{PhD}, \mathrm{ScD}^{1}$; Setonde Romeo D. Konnon, $\mathrm{PhD}^{1}$; \\ Maya T. Khubetsova, $\mathrm{PhD}^{1}$; Irina V. Savenkova ${ }^{1}$; Anastasia V. Minaeva ${ }^{1}$; \\ Dmitriy S. Novginov ${ }^{1}$; Vitaliy N. Kretsu ${ }^{1}$; Aleksey A. Lukaev, MD ${ }^{2 *}$ \\ ${ }^{1} R U D N$ University, Moscow, Russia \\ ${ }^{2}$ Mytischi City Clinical Hospital Mytishchi, Moscow Region, Russia
}

\begin{abstract}
Premature birth (PB) is associated with placental insufficiency, which is confirmed in the morphological study of the placenta. Ultrasonic markers of placental abnormalities, often preceding PB, have been identified: changes in placental structure, premature ripening of the placenta, oligohydramnios, and fetal-placental circulation.(International Journal of Biomedicine. 2018;8(1):42-46.)
\end{abstract}

Key Words: oligohydramnios $\bullet$ intrauterine growth retardation $\bullet$ cervicometry $\bullet$ premature birth

\section{Abbreviations}

IUGR, intrauterine growth retardation; PR, perinatal risk; PB, premature birth.

\section{Introduction}

Premature birth (PB) is a multifactorial obstetrical complication, which should be predicted by taking into account the risk factors; the leading factors are infectious and inflammatory diseases of the genitourinary system, a burdened reproductive history of the mother (sexual debut before the age of 16, the early reproductive loss in the anamnesis) and tobacco smoking. The close interweaving of socio-biological factors and infectious and non-infectious factors, in combination with neuroendocrine disorders, create prerequisites for the placental insufficiency formation and disorders of uteroplacental and fetal-placental circulation. Currently, there is no clear evidence for the impact of perinatal risk (PR) on the outcome of PB. Numerical reflection of the degree of burden of the anamnesis and the course of pregnancy is the number of points of PR.

There is evidence of the leading role of placental insufficiency in the pathogenesis of premature termination of

"Corresponding author: Aleksey A. Lukaev, MD. Mytishchi City Clinical Hospital, Mytishchi, Moscow Region, Russia E-mail: alekseilukaev@mail.ru pregnancy. ${ }^{(1,2)}$ The length of the cervix is the predictor of $\mathrm{PB}$. Berghella and colleagues ${ }^{(3)}$ indicated in their studies that the short cervix, measured with transvaginal ultrasound, is a risk for PB. Changes in the cervix are a more objective indicator than the evaluation of labor. If the length of the cervix is more than $3 \mathrm{~cm}$, the probability of labor in the next week is about $1 \%$. Ultrasonic cervicometry is an objective, less invasive and more accurate method of assessing the patient's condition compared with a vaginal manual examination. ${ }^{(4)}$

The aim of this research was to assess the results of fetal ultrasound imaging and Doppler ultrasound study depending on the PR factors in PB.

\section{Materials and Methods}

The study was performed in Municipal clinical hospital \#29 named after N.E. Bauman. We carried out a prospective analysis of 236 medical records of pregnant women with premature labor at 28 to 33 weeks (plus 6 days) of gestation (ICD10 code 060$){ }^{(5)}$ According to premature labor classification, all pregnant women were divided into 2 cohorts: Cohort 1 (gestational age from 28 to 30 weeks plus 6 days) and Cohort 2 (gestational age from 31 to 33 weeks plus 6 days). Depending 
on the number of PR factors, each cohort was divided into 3 groups: a low PR, a moderate PR, and a high PR (Table 1).

\section{Table 1.}

Distribution of the examined women

\begin{tabular}{|c|c|c|c|c|c|}
\hline \multicolumn{3}{|c|}{$\begin{array}{c}\text { Cohort 1 } \\
n=128\end{array}$} & \multicolumn{3}{c|}{$\begin{array}{c}\text { Cohort 2 } \\
n=108\end{array}$} \\
\hline $\begin{array}{c}1^{\text {st }} \text { group } \\
\text { Low PR }\end{array}$ & $\begin{array}{c}2^{\text {nd }} \text { group } \\
\text { Moderate PR }\end{array}$ & $\begin{array}{c}3^{\text {rd }} \text { group } \\
\text { High PR }\end{array}$ & $\begin{array}{c}1^{\text {st }} \text { group } \\
\text { Low PR }\end{array}$ & $\begin{array}{c}2^{\text {nd }} \text { group } \\
\text { Moderate PR }\end{array}$ & $\begin{array}{c}3^{\text {rd }} \text { group } \\
\text { High PR }\end{array}$ \\
\hline $\mathrm{n}=20$ & $\mathrm{n}=38$ & $\mathrm{n}=70$ & $\mathrm{n}=32$ & $\mathrm{n}=52$ & $\mathrm{n}=24$ \\
\hline
\end{tabular}

A specific group for PR was defined in accordance with the number of points derived from S. Knyazev's scale (2003): low risk (<15points), moderate risk (from 15 to 20 points), and high risk ( $\geq 25$ points). Calculation of PR factors was performed twice: at admission and during labor. We identified the degree of PR based on the scale developed by O.G. Frolova and E.I. Nikolaeva (1981) and modified by V.E. Radzinsky et al. ${ }^{(6)}$

Statistical analysis was performed using the statistical software «Primer of Biostat 4.0» and «STATISTICA 7». Group comparisons with respect to categorical variables are performed using chi-square tests with Yates correction or, alternatively, Fisher's exact test when expected cell counts were less than 5 . A probability value of $P<0.05$ was considered statistically significant.

\section{Results and Discussion}

Fetometry showed that IUGR was diagnosed in $71 / 30.1 \%$ patients. The degree 1 of IUGR was diagnosed in $49 / 20.8 \%$ pregnant women, and degrees 2 and 3 in 17/7.2\% and $5 / 2.1 \%$ pregnant women, respectively. An analysis of the frequency of IUGR revealed significant $(P<0.05)$ differences depending on the degree of PR. The main share of women with IUGR comprised those with a high PR in Cohort 1 and those with a high and moderate PR in Cohort 2 (Table 2).

Table 2.

Frequency of IUGR in the examined women

\begin{tabular}{|c|c|c|c|c|c|c|c|}
\hline \multirow{3}{*}{$\begin{array}{l}\frac{1}{0} \\
\frac{\pi}{0} \\
0\end{array}$} & \multirow{3}{*}{ Degree of PR } & \multicolumn{6}{|c|}{ IUGR } \\
\hline & & \multicolumn{2}{|c|}{ I } & \multicolumn{2}{|c|}{ II } & \multicolumn{2}{|c|}{ III } \\
\hline & & $\mathrm{n}$ & $\%$ & $\mathrm{n}$ & $\%$ & $\mathrm{n}$ & $\%$ \\
\hline \multirow{3}{*}{ I } & Low $(n=20)$ & 2 & 10.0 & 1 & 5.0 & 0 & 0.0 \\
\hline & Moderate $(\mathrm{n}=38)$ & 7 & 18.4 & 4 & 5.1 & 0 & 0.0 \\
\hline & $\operatorname{High}(\mathrm{n}=70)$ & 21 & $30.0^{*}$ & 5 & 7.1 & 1 & 1.4 \\
\hline \multirow{3}{*}{ II } & Low $(n=32)$ & 3 & 9.3 & 0 & 0 & 0 & 0.0 \\
\hline & Moderate $(n=52)$ & 15 & $28.8^{*}$ & 2 & 3.8 & 0 & 0.0 \\
\hline & High $(n=24)$ & 1 & 4.2 & 5 & 20.8 & 4 & 16.7 \\
\hline & Total $(n=236)$ & 49 & 20.8 & 17 & 7.2 & 5 & 2.1 \\
\hline
\end{tabular}

$*_{-} P<0.05$ in relation to the high PR group of Cohort 2
Diagnosis of IUGR was confirmed in only $16 / 22.5 \%$ newborns. This situation is explained by the fact that the criteria for ultrasound diagnosis of IUGR differ from clinical diagnosis of IUGR, in accordance with centile scales: body weight, length, and circumference of the head and chest.

More reliably, IUGR was diagnosed in women with a high PR in Cohort 2 - in every other newborn born to a mother with an antenatally diagnosed IUGR (Table 3).

Table 3.

\section{Identified IUGR in premature infants at birth}

\begin{tabular}{|c|l|c|c|c|}
\hline \multirow{2}{*}{ Cohort } & \multirow{2}{*}{ Degree of PR } & \multirow{2}{*}{$\mathrm{n}$} & \multicolumn{2}{|c|}{ IUGR } \\
\cline { 4 - 5 } & & & $\mathrm{n}$ & $\%$ \\
\hline \multirow{3}{*}{ I } & Low $(\mathrm{n}=20)$ & 3 & 1 & 33.3 \\
\cline { 2 - 5 } & Moderate $(\mathrm{n}=38)$ & 8 & 2 & 25 \\
\cline { 2 - 5 } & High $(\mathrm{n}=70)$ & 12 & 4 & 33.3 \\
\hline \multirow{3}{*}{ II } & Low $(\mathrm{n}=32)$ & 17 & 2 & $11.8^{*}$ \\
\cline { 2 - 5 } & Moderate (n=52) & 23 & 3 & $13^{*}$ \\
\cline { 2 - 5 } & High (n=24) & 8 & 4 & 50 \\
\hline \multirow{2}{*}{ Total } & 71 & 16 & 22.5 \\
\hline
\end{tabular}

$*_{-} P<0.05$ in relation to the high PR group of Cohort 2

The evaluation of the degree of maturity of the placenta according to Grannum et al. ${ }^{(7)}$ obtained the following results: Grade 0 of maturity of the placenta was significantly more often diagnosed in women with a low and moderate PR in Cohort 1 (45\% and 36.8\%, respectively) and a low PR in Cohort 2 (34.4\%). Ultrasonic signs of premature aging of the placenta (Grades II and III) were diagnosed in $87 / 36.9 \%$ of pregnant women $(P<0.05)$. In this case, statistical significance was noted in Cohort 2 in all groups with Grade III of maturity of the placenta $(P<0.05)$. Grade III of maturity of the placenta was more often diagnosed in women with a high PR in Cohort 2 (Table 4).

\section{Table 4.}

\section{Grade of maturity of the placenta}

\begin{tabular}{|c|c|c|c|c|c|c|c|c|c|}
\hline \multirow{3}{*}{$\begin{array}{l}\frac{1}{0} \\
\frac{1}{0}\end{array}$} & \multirow{3}{*}{ Degree of PR } & \multicolumn{8}{|c|}{ Grade of maturity of the placenta } \\
\hline & & \multicolumn{2}{|r|}{0} & \multicolumn{2}{|r|}{ I } & \multicolumn{2}{|c|}{ II } & \multicolumn{2}{|c|}{ III } \\
\hline & & $\mathrm{n}$ & $\%$ & $\mathrm{n}$ & $\%$ & $\mathrm{n}$ & $\%$ & $\mathrm{n}$ & $\%$ \\
\hline \multirow{3}{*}{ I } & Low $(n=20)$ & 9 & $45.0 *$ & 7 & 35.0 & 4 & 20.0 & 0 & 0.0 \\
\hline & Moderate $(n=38)$ & 14 & $36.8 *$ & 9 & 23.7 & 12 & 31.6 & 3 & 7.9 \\
\hline & High $(n=70)$ & 4 & 5.7 & 38 & $54.3^{*}$ & 23 & 32.9 & 5 & 7.1 \\
\hline \multirow{3}{*}{ II } & Low $(n=32)$ & 11 & $34.4 *$ & 15 & 46.9 & 5 & 15.6 & 1 & $3.1 *$ \\
\hline & Moderate $(\mathrm{n}=52)$ & 8 & 15.4 & 26 & 50.0 & 11 & 21.2 & 7 & $13.5^{*}$ \\
\hline & High $(n=24)$ & 1 & 4.2 & 7 & 29.2 & 5 & 20.8 & 11 & 45.8 \\
\hline & Total $(n=236)$ & 47 & 19.9 & 102 & 43.2 & 60 & 25.4 & 27 & 11.4 \\
\hline
\end{tabular}

$*_{-} P<0.05$ in relation to the high PR group in each Cohort 
The data obtained when measuring the thickness of the placenta ranged from $31.0 \mathrm{~mm}$ to $37.2 \mathrm{~mm}$ and averaged $32.4 \pm 0.3 \mathrm{~mm}$.

Disorders in the uteroplacental and fetal-placental circulation were detected in 79 (33.5\%) of pregnant women (2 and 3 degree in $16[20.2 \%$ ] women). These disorders were most common in groups of women with a moderate PR (Table 5).

Table 5.

Disorders in the uteroplacental and fetal-placental circulation

\begin{tabular}{|c|c|c|c|c|c|c|c|c|c|c|}
\hline \multirow{2}{*}{$\begin{array}{l}\frac{1}{0} \\
\frac{\pi}{0} \\
0\end{array}$} & \multirow{2}{*}{ Degree of PR } & \multirow{2}{*}{$\mathrm{n}$} & \multicolumn{2}{|c|}{ IA } & \multicolumn{2}{|c|}{ IB } & \multicolumn{2}{|c|}{ II } & \multicolumn{2}{|c|}{ III } \\
\hline & & & $\mathrm{n}$ & $\%$ & $\mathrm{n}$ & $\%$ & $\mathrm{n}$ & $\%$ & $\mathrm{n}$ & $\%$ \\
\hline \multirow{3}{*}{ I } & Low $(n=20)$ & 7 & 4 & 57.1 & 3 & 42.9 & 0 & 0.0 & 0 & 0.0 \\
\hline & Moderate $(n=38)$ & 12 & 5 & 41.7 & 4 & 33.3 & 2 & 16.7 & 1 & 8.3 \\
\hline & $\operatorname{High}(\mathrm{n}=70)$ & 11 & 8 & 72.7 & 3 & 27.3 & 0 & 0.0 & 1 & 9.1 \\
\hline \multirow{3}{*}{ II } & Low $(n=32)$ & 18 & 10 & 55.6 & 2 & 11.1 & 4 & 22.2 & 2 & 11.1 \\
\hline & Moderate $(\mathrm{n}=52)$ & 20 & 13 & 65.0 & 7 & 35.0 & 0 & 0.0 & 0 & 0.0 \\
\hline & High $(n=24)$ & 11 & 4 & 36.4 & 1 & 9.1 & 2 & 18.2 & 4 & 36.4 \\
\hline \multicolumn{2}{|c|}{ Total $(n=236)$} & 79 & 44 & 55.7 & 20 & 25.3 & 8 & 10.1 & 8 & 10.1 \\
\hline
\end{tabular}

The pathology of the amniotic fluid was determined in $137 / 58.1 \%$ pregnant women. In structure of the pathology of the amniotic fluid, oligohydramnios was predominant (45.3\%). Oligohydramnios was diagnosed 2 to 3 times more often in women with high to moderate PR compared to women with a low PR. Polyhydramnios was found in 30(12.7\%) women (Table 6). It should be noted that as the gestational age increased, the frequency of detection of oligohydramnios increased significantly $(P<0.05)$.

Table 6.

The pathology of the amniotic fluid

\begin{tabular}{|c|l|c|c|c|c|}
\hline \multirow{3}{*}{ Cohort } & \multirow{2}{*}{ Degree of PR } & \multicolumn{2}{|c|}{ Oligohydramnios } & \multicolumn{2}{c|}{ Polyhydramnios } \\
\cline { 3 - 6 } & & $\mathrm{n}$ & $\%$ & $\mathrm{n}$ & $\%$ \\
\hline \multirow{3}{*}{ I } & Low (n=20) & 4 & $20.0 *$ & 2 & 10.0 \\
\cline { 2 - 6 } & Moderate (n=38) & 14 & 36.8 & 7 & 18.4 \\
\cline { 2 - 6 } & High (n=70) & 34 & 48.6 & 11 & 15.7 \\
\hline \multirow{3}{*}{ II } & Low (n=32) & 7 & $21.9 * / * *$ & 5 & $15.6 * *$ \\
\cline { 2 - 7 } & Moderate (n=52) & 32 & 61.5 & 1 & $1.9 *$ \\
\cline { 2 - 7 } & High (n=24) & 16 & 66.7 & 4 & 16.7 \\
\hline \multicolumn{2}{|c|}{ Total (n=236) } & 107 & 45.3 & 30 & 12.7 \\
\hline
\end{tabular}

$*_{-} P<0.05$ in relation to the high PR group in each Cohort $*_{*} *_{-}<0.05$ in relation to the moderate $P R$ group in each Cohort

Ultrasonic cervicometry, as a promising method for diagnosing and predicting the outcome of PL, was preceded by a determination of the degree of "maturity" of the cervix, according to E. Bishop.$^{\left({ }^{8}\right)}$ The study showed that approximately half $(114 / 51.6 \%)$ of the pregnant woman entered the hospital with a "maturing" cervix, of which every third (61/27.6\%) woman was in Cohort 1 with a moderate PR. The "immature" cervix was identified in $33 / 15.0 \%$ women in Cohort 1 and $31 / 14.0 \%$ in Cohort 2 with a low PR. Pregnant women in Cohort 1 with the low and moderate PR had an "immature" cervix significantly more often, and, despite the ongoing medical and diagnostic measures, they developed labor activity. The smallest share was presented by women with the "mature" cervix, and of them, $14 / 40 \%$ were in Cohort I with moderate risk and had a degree of maturity of the uterine cervix from 9 to 13 points (Table 7).

Table 7.

Degree of maturity of the uterine cervix, according to E. Bishop

\begin{tabular}{|c|c|c|c|c|c|c|c|c|}
\hline \multirow{2}{*}{$\begin{array}{l}\text { E. } \\
\text { ठ }\end{array}$} & \multirow{2}{*}{ Degree of PR } & \multirow{2}{*}{$\mathrm{n}$} & \multicolumn{2}{|c|}{$\begin{array}{l}\text { "immature" } \\
\text { (0-5 points) }\end{array}$} & \multicolumn{2}{|c|}{$\begin{array}{l}\text { "ripening" } \\
\text { (6-8 points) }\end{array}$} & \multicolumn{2}{|c|}{$\begin{array}{l}\text { "mature" } \\
\text { (9-13 points) }\end{array}$} \\
\hline & & & $\mathrm{n}$ & $\%$ & $\mathrm{n}$ & $\%$ & $\mathrm{n}$ & $\%$ \\
\hline \multirow{3}{*}{ I } & Low & 18 & 11 & $61.1 *$ & 3 & $16.7^{*}$ & 4 & 22.2 \\
\hline & Moderate & 35 & 12 & $34.3^{*}$ & 9 & $25.7 *$ & 14 & $40.0 *$ \\
\hline & High & 64 & 10 & 15.6 & 49 & 76.6 & 5 & 7.8 \\
\hline \multirow{3}{*}{ II } & Low & 28 & 10 & 35.7 & 13 & 46.4 & 5 & 17.9 \\
\hline & Moderate & 52 & 13 & 25.0 & 31 & 59.6 & 8 & 15.4 \\
\hline & High & 24 & 8 & 33.3 & 9 & 37.5 & 7 & 29.2 \\
\hline & Total & 221 & 64 & 29.0 & 114 & 51.6 & 43 & 19.5 \\
\hline
\end{tabular}

$*_{-} P<0.05$ in relation to the high PR group in each Cohort

The average cervical length was $21.06 \pm 6.93 \mathrm{~mm}$, while the maximum cervical length was $28.9 \mathrm{~mm}$, and the minimum length $-13.2 \mathrm{~mm}$. The results of ultrasound data on structural changes in the cervix at threat of PB are presented in Table 8.

\section{Table 8.}

\section{Ultrasound data on structural changes in the cervix}

\begin{tabular}{|c|c|c|c|c|c|c|c|c|c|c|}
\hline \multirow[t]{2}{*}{$\begin{array}{l}\frac{\pi}{0} \\
\frac{0}{0} \\
0\end{array}$} & \multirow[t]{2}{*}{$\begin{array}{l}\text { Degree } \\
\text { of PR }\end{array}$} & \multirow[t]{2}{*}{$\mathrm{n}$} & \multicolumn{2}{|c|}{$\begin{array}{l}\text { cervical } \\
\text { length } \\
>2.5 \mathrm{~cm}\end{array}$} & \multicolumn{2}{|c|}{$\begin{array}{l}\text { cervical } \\
\text { length } \\
<2.5 \mathrm{~cm}\end{array}$} & \multicolumn{2}{|c|}{$\begin{array}{c}\text { cervical } \\
\text { canal } \\
\text { width } \\
\geq 1 \mathrm{~cm}\end{array}$} & \multicolumn{2}{|c|}{$\begin{array}{c}\text { V-shaped } \\
\text { deformation } \\
\text { of the internal } \\
\text { throat cervix }\end{array}$} \\
\hline & & & $\mathrm{n}$ & $\%$ & $\mathrm{n}$ & $\%$ & $\mathrm{n}$ & $\%$ & $\mathrm{n}$ & $\%$ \\
\hline \multirow{3}{*}{ I } & Low & 18 & 4 & $22.2 *$ & 14 & $77.8^{*}$ & 4 & 22.2 & 3 & $16.7^{*}$ \\
\hline & Moderate & 35 & 8 & $22.9^{*}$ & 27 & $77.1^{*}$ & 9 & 25.7 & 1 & $2.9^{*}$ \\
\hline & High & 64 & 41 & 64.1 & 23 & 35.9 & 12 & 18.8 & 39 & 60.9 \\
\hline \multirow{3}{*}{ II } & Low & 28 & 6 & 21.4 & 22 & 78.6 & 8 & 28.6 & 8 & $28.6 * *$ \\
\hline & Moderate & 52 & 19 & 36.5 & 33 & 63.5 & 17 & 32.7 & 44 & $84.6^{*}$ \\
\hline & High & 24 & 8 & 33.3 & 16 & 66.7 & 5 & 20.8 & 3 & 12.5 \\
\hline & Total & 221 & 86 & 38.9 & 135 & 61.1 & 55 & 24.9 & 98 & 44.3 \\
\hline
\end{tabular}

*- $P<0.05$ in relation to the high PR group in each Cohort ** $-P<0.05$ in relation to the moderate PR group in each Cohort 


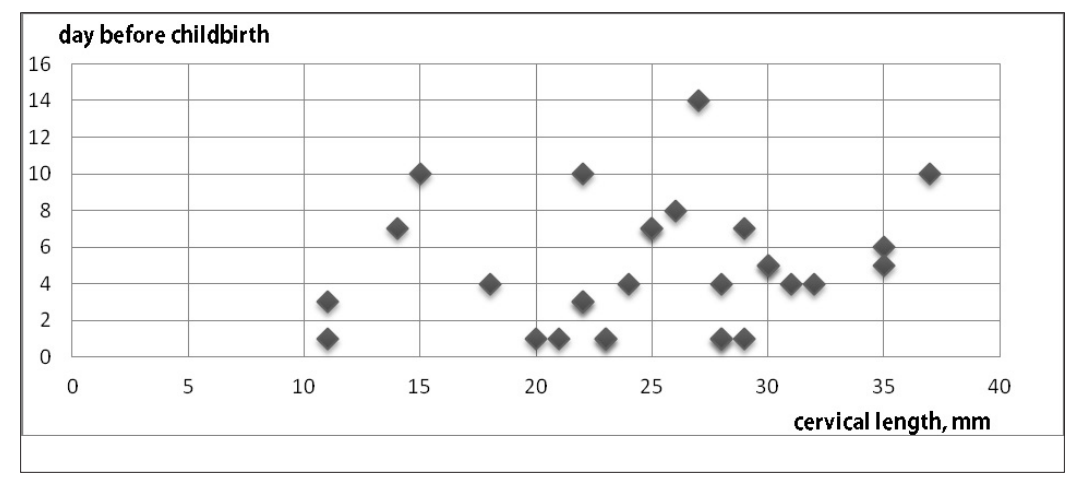

Fig. 1. The cervical length.

It should be noted that the short cervix was seen both for several weeks before delivery and for several days before delivery. Such data were noted in all groups (Figure 1).

\section{Conclusion}

The neonatal period carries higher morbidity and mortality than the rest of infancy and childhood combined. Two important measures associated with neonatal outcomes are gestational age and birthweight..$^{(9,10)}$ In accordance with ICD-10, newborns classified as "small for gestational age" are those who are smaller in size than normal for the gestational age, most commonly defined as a weight and length below the 10th percentile for the gestational age. ${ }^{(11,12)}$ Currently, the analysis of publications shows an absence of generalized data on the features of the course of pregnancy and childbirth in cases of intrauterine growth retardation and premature birth. There are certain difficulties in the accurate and objective diagnosis of placental insufficiency, and there are no clear criteria for evaluating its various forms. This leads to the possibility of overdiagnosis of the decompensated form of placental insufficiency and hypodiagnosis of the compensated form of placental insufficiency.

Fetoplacental insufficiency averaged 39.8\%. Intrauterine growth retardation was significantly $(P<0.05)$ more often diagnosed in pregnant women with moderate and high perinatal risk regardless of the analyzed gestational periods - an average in $32.6 \%$ of women with premature birth. In pregnant women with a low perinatal risk, intrauterine growth retardation was diagnosed reliably less often-in $8 \%$ of cases. We found that intrauterine growth retardation was diagnosed in every third (30.1\%) examined pregnant woman. However, the diagnosis of intrauterine growth retardation was confirmed in only $16(22.5 \%)$ newborns according to centile scales. A weak direct relationship between oligohydramnios and intrauterine growth retardation in Cohort $1(\mathrm{r}=0.364$, $P<0.05)$ and in Cohort $2(\mathrm{r}=0.39, P<0.001)$ was revealed.

Disorders in the uteroplacental and fetal-placental circulation were detected in $79(33.5 \%)$ of pregnant women (2 and 3 degree in 16[20.2\%] women). These disorders were most common in groups of women with a moderate perinatal risk. The amniotic fluid pathology was determined in $137(58.1 \%)$ pregnant women. In structure of the amniotic fluid pathology, oligohydramnios was predominant (45.3\%). Oligohydramnios was diagnosed 2 to 3 times more often in women with high to moderate perinatal risk compared to women with a low perinatal risk. It should be noted that as the gestational age increased, the frequency of detection of oligohydramnios increased significantly $(P<0.05)$.

The results of assessing the state of the cervix clearly demonstrate the lack of effectiveness of tocolytic therapy in $51.6 \%$ of pregnant women (cervical ripening). In the remaining pregnant women with an "immature" cervix, cervicometry revealed istmiko-cervical insufficiency, that is, already at the time of 16-19 weeks of gestation the mechanism of anatomical transformation in the cervix was started, not diagnosed in time.

\section{Competing interests} interests.

The authors declare that they have no competing

\section{Sources of Funding}

The study was supported by the RUDN University Program 5-100.

\section{References}

1. PestrikovaTU,YurasovaEA,ButkoTM.Pathomorphological characteristics of the individual links of the mother-placentafetus system in premature delivery. Akusherstvo i Ginekologiya. 2002; (3): 25-28. [Article in Russian].

2. Sidelnikova VM, Antonov AG. Premature birth. Premature baby. Moscow: GEOTAR-Media; 2006. [in Russian].

3. Berghella, V., Rafael T.J., Szychowski J.M. et al. Cerclage for short cervix on ultrasonography in women with singleton gestations and previous preterm birth: a meta-analysis. Obstet Gynecol. 2011;117(3):663-71.

4. Berghella B, Rafael TJ, Szychowski JM, Rust OA, Owen J. Cerclage for short cervix on ultrasonography in women with singleton gestations and previous preterm birth: a metaanalysis. Obstet Gynecol. 2011;117(3):663-71. 
5. World Health Organization (1992) International Statistical Classification of Diseases and Related Health Problems. Tenth Revision. Vol 1: Tabular list. WHO, Geneva, 1992

6. Radzinsky VE, Knyazev CA, IN Kostin. Obstetric risk. Maximum of information - Mminimum of danger to the mother and baby. M.: Eksmo; 2009, 290 pp. [in Russian].

7. Grannum PA, Bercovitz RL, Hobbins JC. The ultrasonic changes in the maturing placenta and their relation to fetal pulmonic maturity. Am J Obstet Gynec. 1979;133(8):915-22. 8. Bishop EH. Pelvic scoring for elective induction. Obst Ginecol. 1964;24(2):266-8

9. McCormick MC.The contribution of low birth weight to infant mortality and childhood morbidity.N Engl J Med. 1985
Jan 10;312(2):82-90.

10. Hamilton BE1, Hoyert DL, Martin JA, Strobino DM, Guyer B. Annual summary of vital statistics: 2010-2011. Pediatrics. 2013 Mar;131(3):548-58. doi: 10.1542/peds.20123769. Epub 2013 Feb 11.

11. World Health Organisation. Intrauterine growth retardation in newborn children. Available from: http://www. who.int/ceh/indicators/iugrnewborn.pdf (WHO, 2015).

12. Ewing AC, Ellington SR, Shapiro-Mendoza CK, Barfield WD, Kourtis AP. Full-Term Small-for-Gestational-Age Newborns in the U.S.: Characteristics, Trends, and Morbidity. Matern Child Health J. 2017 Apr;21(4):786-796. doi: 10.1007/ s10995-016-2165-Z 